\title{
STRENGTHENING OF SCHOOL QUALITY THROUGH SCHOOL PRINCIPAL LEADERSHIP
}

Wresni Pujiyati

\author{
IPostgraduate Program, Wiralorda University, Indonesia \\ $\bowtie$ wresni.pujiyati@unwir.ac.id
}

\begin{abstract}
This study aims to analyze and find out the implementation of principals 'leadership through school quality with the long-term goal of improving the quality of schools through principals' leadership. The specific target of this research is to develop a principal's leadership model. The research method uses a qualitative approach through case studies through observation, interviews, document studies relating to the principal's leadership and school quality. The general conclusion is that improving school quality is a process towards the realization of quality schools. Principal's leadership in strengthening school quality can be found in (1) Improving school quality (2) Principal's leadership strategy in improving school quality.
\end{abstract}

Keywords: principal school leadership, school quality

INTRODUCTION Academic The EFA (Education Forum on Education for All) focuses on discussing the quality of education in each of its frameworks and objectives (Laurie et al. 2016). Education has become the goal of education policy. To that end, the national education system develops and promotes measures of quality education in the form of education indicators that lead to quality education into the accountability system. (Engel \& Rutkowski, 2014). To extend this scholarship, the purpose of this study is to analyze and find out the implementation of the principal's leadership through school quality.

Relevant studies by Oktriany \& Triastuti (tt) report that education quality standards refer to National Education Standards which consist of content standards, process standards, graduate competency standards, teacher and education staff standards, facilities and infrastructure standards, school management standards, funding standards, and education assessment standards

\section{Literature Review}

\section{Principal's Leadership}

A good leader inspires commitment to the core purposes of the organization (Hoy et al. 2000). This opinion can be analyzing that the goals of an organization have achieved by the role of leadership, including leadership, inspires commitment to the core goals of the organization.

Principal's leadership has called academic leadership, as stated by Ervay (2006), that "academic leadership has traditionally been seeing as the responsibility of certified administrators." In this case, certified administrators have referred to as school principals whose job is to guide teachers to be competent and professional.

Implementation of school principals' leadership in improving the quality of education is done by managing activities related to education and teaching, student affairs, staffing, community relations, and infrastructure. Besides, the principal also has a role as a leader and 
supervisor (Pidarta, 2011)

Imhangbe et al. described the Principal's Leadership, (2018)that: 1) The principal as part of his legal contribution to the health and success of the school, to carry out several administrative functions, including regular teaching supervision. 2) The principal is to assist and guide teachers to translate national policy provisions on education and curriculum or syllabus contents into lessons that have applied to learn. 3) Director, instructional instructor, advisor, public relations officer, current director, head of an education office, school principal

Okinyi et al. (2015) describe the specific behavior of principals where students have the potential to achieve academic success: (1) The principal supports the teaching methods of teachers and modification of their approaches and teaching materials. (2) The principal allocates resources and materials. (3) The principal often visits classrooms for teaching purposes. (4) The first requests and provides feedback about teaching methods and techniques. (5) The principal uses data to focus attention on improving the curriculum or teaching approach to maximizing student achievement. (6) School principals use faculty data and input to determine staff development activities that strengthen teacher teaching skills.

Edwards et al. 2015 state leadership is "as a way of being-in-relation-to-others." It has analyzed that leadership is an interaction with other members.

Leadership was presented by Pandit \& Jhamtani, 2011 related to 1) Leadership Style 2) Organizational Climate 3) harmonized and motivated workers. Avolio's opinion presented by Hofmeyer et al. That leadership is defining as traits, characteristics, and behaviors that focus on vision, action, modeling, relationships, congruence, trust, and collaboration. (Hofmeyer, et al. 2015).

From the opinions of Edwards et al. 2015, Pandit \& Jhamtani 2011, and Avolio, it can be concluding that leadership is an interaction with other members that focuses on vision, action, modeling, relationships, congruence, trust, and collaboration. This interaction is influencing by leadership style, organizational climate, and workers who are in harmony and motivated

Leadership behavior, according to Usman, explained the behavior as a style of attitude and action, including how to command, how to make decisions, how to motivate, how to communicate, how to coordinate (Rosdina et al. 2015). Leadership style, according to Chen \& Silverthorne (2005), leadership styles involved in relationship-oriented behavior have a positive relationship with satisfaction and performance (e.g., Wilkinson and Wagner, 1993). From this opinion, it has analyzed that leadership style related to behavior that has a positive relationship with job satisfaction and performance.

From the opinion of Usman, Chen \& Silverthorne, 2005, it can be analyzed that leadership style is related to behavior while behavior being a style of attitude, the action includes how to command, how to make decisions, how to motivate, how to communicate, how coordinate. It has concluded that the leadership style is the way to govern, how to make decisions, how to motivate, how to communicate, how to coordinate while the concept of leadership is a trait, characteristic, and behavior that focuses 
on vision, action, modeling, relationships, congruence, trust, and collaboration.

Principal Competency Standards refer to the Decree of the Minister of National Education of the Republic of Indonesia Number 13 of 2007, and the Appendix to the Regulations are as follows 1) Personality competence 2) Managerial Competence 3) Entrepreneurship Competence. 4) Competency supervision, 5) Social competence.

From the explanation of the competency of the principal, it has analyzed that the competency of the principal includes personality competence, managerial competence, entrepreneurial competence, supervisory competence, social competence.

Overall about the concepts of leadership: leadership behavior, leadership style, competency of principals, it has concluded that the principal's leadership is a trait, characteristic, and behavior that focuses on vision, action, modeling, relationships, congruence, trust, and collaboration based on managerial ability, entrepreneurship, supervision, as well as having personality competencies and social competencies that has set.

Principal leadership indicators (Imhangbe, 2018 \& Okinyi, 2015) as follows:

(1) The principal, as part of his legal contribution to the health and success of the school, to carry out several administrative functions, including regular teaching supervision.

(2) The principal is to assist and guide teachers to translate the provisions of national policies on education and the contents of the curriculum or syllabus into lessons that can be applying to learn activity.
(3) Director, instructional instructor, advisor, public relations officer, current director, head of education office, school principal

(4) The principal supports the teaching methods of teachers and the modification of their approaches and teaching materials.

(5) The principal allocates resources and materials.

(6) The principal often visits classrooms for teaching purposes.

(7) The first requests and provides feedback on teaching methods and techniques.

(8) The principal uses data to focus attention on improving the curriculum or teaching approach to maximizing student achievement.

(9) Principals use faculty data and input to determine staff development activities that strengthen teacher teaching skills.

\section{School Quality}

Sallis (2002) states that "quality is achieved by putting systems and procedures into operation and ensuring that those systems are efficiently and effectively operating." This explanation can be analyzing that quality has achieved by using systems and procedures. These systems and procedures are operating efficiently and effectively.

School quality according to Hoy, et al. (2000) states that "Quality in Education is an evaluation of the process of educating which enhances the need to achieve and develop the talents of the customers of the process, and at the same time meets the accountability standards set by the clients who pay for the process or the output from the process of educating. "This opinion can be analyzed that quality in education is 
an evaluation of the educational process that enhances, attains, and develops customer talent from the process. At the same time, to meet the accountability standards set by the client for the output of the educating process.

Fadli explained the opinion of Sallis, 2005, that quality is an essential part of most organizational agendas (Fadhli, 2017). Quality indicators are (1) high moral values (2) excellent examination results (excellent test results) (3) the support of parents, business and the local community (support of parents, business, and society local) (4) plentiful resources (abundant resources) (5) the application of the technology (6) purposeful and robust leadership (strong and directed leadership) (7) the care and concern for pupils and students (concern forstudents) (8) a well-balanced and challenging curriculum.

Quality when referring to Government Regulation No. 19 of 2005 National Education Standards include: (1) content standards whose scope is the material and level of competence (2) process standards, related to the implementation of learning to achieve graduate competency standards (3) graduate competency standards (4) standards of educators and teaching staff, related to educational criteria (5) infrastructure facilities standards, relating to the minimum criteria of learning spaces, places to exercise, places of worship, libraries, laboratories, workshops, playgrounds, places of creation and recreation and other learning resources (6) related management standards with the planning, implementation, and supervision of educational activities (7) financing standards, relating to the operating costs component of education units (8) education assessment standards, related to the mechanisms, procedures, and instruments of assessment of learning outcomes

The principles in defining the quality of education first are the cognitive development of students, and the second is the role of education in promoting the values and attitudes of citizenship in maintaining creative and emotional development (Laurie et al. 2016). Moral values, for example, respect for life and independence, honesty, tolerance, self-discipline, courtesy, responsibility towards others, generosity, compassion, courage, (Hayati, t.t).

From the opinion of Sallis (2002), Engel \& Rutkowski (2016), Hoy, et al. (2000), Laurie, et al. (2016). That contains the quality of education is a system and procedure, that refers to the historical, cultural, and contextual that is operated efficiently and effectively through evaluations to improve, achieve and develop customer talent from the process and meet the accountability standards set by the client for the output of the educating process through the cognitive development of learners, promote the values and attitudes of citizenship and maintain creative and emotional development.

It contains school quality is a trait, characteristic, and behavior. That focuses on vision, action, modeling, relationships, congruence, trust. Collaboration carried out in the form of systems and procedures that refer to historical, cultural, contextual which are operated efficiently and effectively through evaluations to enhance, achieve, and develop customer talent and meet the accountability standards set by clients for the output of the educating process through the cognitive 
development of learners, promoting the values and attitudes of citizenship and nurturing creative and emotional development.

Quality indicators (from the opinion of Sallis 2002, Engel \& Rutkowski 2016, Hoy, et al. 2000, Laurie, et al. 2016) as follows:

(1) high moral values;

(2) excellent examination results;

(3) the support of parents, business and the local community;

(4) plentiful resources;

(5) the application of the technology;

(6) purposeful and robust leadership;

(7) the care and concern for pupils and students;

(8) a well-balanced and challenging curriculum;

(9) content standards;

(10) process standards;

(11) graduate competency standards;

(12) standards of educators and education personnel;

(13) standard of infrastructure;

(14) management standards,

(15) financing standards;

(16) educational assessment standards,

\section{METHODS}

This research uses a qualitative approach by observation, interview, and documentation study techniques. The analysis consists of three interaction activities, namely, data reduction, verification, and triangulation. The process undertaken by researchers in the determination of this case is the existence of schools that are still of low quality in terms of teaching and learning activities and other activities related to school activities in the district of Indramayu. This research has designed through 3 stages, namely 1) the preparation phase, 2) the implementation phase 3) the data processing stage.

The preparation phases. The researcher carried out a preliminary study by studying the initial conditions of the research object after that, find research questions in order to identify what data and information are needed. And then, design data collection instruments.

The implementation phases. The researcher collected data by conducting interviews and study documents to fulfill the data needed. Interviews have conducted with school principals, vice principals, and teachers. The study of documents is precise by analyzing the data obtained.

\section{Data processing and data analysis}

phases. The researcher carried out for identification, data categories, and synthesis validation, describing research findings, identifying concepts found. Finally, prepare the report.

The determination of data sources was done by determining the principal as a key informant by providing correct information and followed by the snowball process technique. While additional data in the form of documents, books, archives, and other sources that explain this educational unit.

Observation is done by passive participatory observation, which is involved in the social situation of the school but is not part of the school. This technique is using

to obtain information and data relating to the objective conditions of high schools, which are difficult to obtain except by making observations. The interview in this study uses in-depth interview techniques 
intending to explore as much as possible from various sources that will provide information about the principal's strategy in improving school quality. The documentation in this study has used to collect data that was already available in the document notes. Documents that are considering relevant to be obtaining include school profile data, student data each year, student achievement data, school organizational structure, school programs, and other relevant documents.

In the verification process, all data collected in this study were processed manually, including coding per item. Then the data results are reduced. The reduction is apparent by selecting the data that answers the research question and then confirming or checking the suitability of the data. After the reduction process is carrying out, the data is interpreting as a whole, and then the researcher triangulates by finding respondents in a literal way to confirm the answers of the data by asking the same question. Then the data validity test is carried out, namely by checking the data validity based on criteria. The criteria for validity are credibility, transferability, dependability, and confirmability.

\section{Data Analysis}

Data analysis conducted in this research is qualitative analysis; the stages of analysis carried out were:

Unit processing (unitization). Researchers carry out data reduction by sorting data, coding, or giving index cards from field notes and collecting documents related to principal school leadership and school quality.

Data categorization. Researchers did data categorization by reducing data related to principal school leadership and school quality by grouping them into related sections. After that, make the code and preview the entire categorization, then the data was analyzed.

Interpretation of data. This interpretation was carried out by the researcher by giving logical and empirical interpretations based on data about the headmaster's leadership and categorized school quality. The purpose of interpretation is to describe using theories about the principal's leadership strategy in improving school quality as a systematization of analysis.

\section{FINDING AND DISCUSSION}

\section{Finding}

1. Improving School Quality

School quality improvement is carried out by the school principal as follows:

Instilling moral values, this is done by the principal by giving citizenship subjects, teaching cooperation, cooperation, honesty, and responsibility.

Support from parents, businesses, and the local community, this was done by forming a school committee.

Directed and robust leadership, this is done by participating, together, and discussing with members.

Concern for students evidenced, forming the character of students and developing their potential and shaping the character of students done through the habit of reading verses of the Qur'an for 15 minutes in the first hour of every day.

A balanced and challenging curriculum, proven by implementing the 2013 curriculum and the principle 
of developing the Education Unit Level Curriculum.

Content standards whose scope is material and level of competence, proven by referring to Permendiknas No. 22 of 2006 concerning standard contents that contain the basic curriculum framework, curriculum structure, learning load, and educational calendar. The curriculum structure was adopted thoroughly, but some were modified. Local Language / Foreign Skills / Language Subjects (Mulok) for Environmental Education (PLH) are modified subjects.

Process standards related to the implementation of learning to achieve graduate competency standards. Process standards in Indramayu 2 Public High School have based on Permendiknas No. 41 of 2007. The standard process is dividing into five stages, namely the preparation of a syllabus, preparation of lesson plans, implementation and control of teaching and learning activities, and preparation of learning evaluation materials and their implementation. Implementation of learning to achieve graduate competency standards is one of the forms of PAKIEM learning, which is active, creative, innovative, effective, and fun learning. For example, by using bilingual for hard science and soft science subjects based on computer media.

Graduate competence standard. Graduates Competency Standards applied by referring to KTSP / Curriculum 2013. Graduation criteria have an average grade at least 7.50 for both written and practical examinations, as well as achieving a minimum grade limit for each subject following those determined by the school. One of the tools to measure the achievement of graduate competencies is the inclusion of minimum achievement criteria per subject.

Infrastructure standards are related to the minimum criteria of learning spaces where to exercise, places of worship, libraries, laboratories, workshops, playgrounds, places to be creative and recreation, and other learning resources. In SMA Negeri 2 Indramayu, the facilities and infrastructure are sufficient to meet the minimum criteria of learning spaces, sports venues, places of worship, libraries, laboratories, workshops, playgrounds, places for creation and recreation.

Management standards related to the planning of implementation and supervision of educational activities. In this Management Standard, emphasizes on a discipline, (orderly culture), reading culture, competitive spirit, honesty, courtesy, culture of shame and family and free from cigarettes, drugs, and drugs b) administration the learning process, curriculum, workforce, students, infrastructure, and finance are carried out in an orderly, efficient and effective manner by implementing ITbased Management Information Systems

Funding standards related to the operating costs component of the education unit. In SMA 2 Indramayu, education funding came from the provincial government, district government, and students' parents 
(committees)

Educational assessment standards related to the mechanism of procedures and instruments for evaluating learning outcomes. The assessment standard refers to Permendiknas No. 20 of 2007. The school developed an authentic assessment instrument that measures three domains of assessment (namely, cognitive, psychomotor, and affective), including portfolio assessment.

2. Principal's Leadership Strategy in Improving School Quality

The principal's leadership strategy in improving school quality is as follows: The principal as part of contributions to the health and success of the school to carry out several administrative functions, including regular teaching supervision. Supervision is carried out by the principal, especially for the supervision of teaching at SMA 2 Indramayu is through supervision.

The principal is to assist and guide teachers to translate national policy provisions on education and curriculum or syllabus contents into lessons that can be applying to learn activity. At SMAN 2 Indramayu, the principal conducts curriculum development to translate national policy provisions regarding education and curriculum content so that it can be applying in learning. For example, by holding teacher council meetings incidentally and periodically, at the beginning of the school year, the teacher is required to prepare a syllabus of subjects to be taught. At the end of the school year, the teacher conducts an assessment of the way and results of his work by reviewing the things that has taught to subsequently hold improvement in the next school year, at the end of the school year conducting research with teachers related to the situation and conditions of the school as a guide to make school programs for the following year.

The principal allocates resources and materials-the principle of SMA Negeri 2 Indramayu in allocating resources and materials using a package system. Time allocation for Structured Assignment (PT) and Independent Structured Activities (KMT) is a maximum of $60 \%$ of the time of face-to-face activities per week for each subject. Time allocation for each subject is 45 minutes per hour. The number of hours of study per week: class $X$ is 44 hours of study, class $X I$ is 44 hours of study, and the addition of 3 hours of study in subjects characteristic of the program and needs. Class XII is 44 hours of study and the addition of 1 lesson each time in English subjects, Mathematics, and Biology for Natural Sciences and Economics programs, and Geography for Social Sciences programs.

The first requests and provides feedback on teaching methods and techniques. The principal of SMA Negeri 2 Indramayu in providing feedback on teaching methods and techniques through dialogue, meetings, and communication tools such as SMS / WhatsApp, and E-mail.

The principal uses data to focus on improving the curriculum or teaching approach to maximizing student achievement. The principal of SMA 
Negeri 2 Indramayu in maximizing student achievement of principals paying attention to the diversity of students' characteristics, local excellence, and regional potential, as well as levels and types of education without distinguishing religion, ethnicity, culture, customs, socioeconomic status, and gender. The curriculum is developing following the vision, mission, and goals of the school.

Principals use faculty data and input to determine staff development activities that strengthen teacher teaching skills. The principal of Indramayu 2 Public High School in determining staff development through training and workshops, IHT programs, and utilizing meetings for Subject Teachers (MGMP)

3. Supporting and Inhibiting Factors of Principal Leadership in Improving School Quality at SMA Negeri 2 Indramayu

Factors supporting and inhibiting the leadership of school principals in improving the quality of schools at SMA Negeri 2 Indramayu are as follows:

Basic Curriculum Framework at SMA Negeri 2 Indramayu, which is describing as containing subjects. Basic Framework The curriculum continues the existing pattern. Only on subjects of citizenship and personality will be sought to find alternative forms of coaching at the point of showing appreciation for esthetic work. In the subject of Aesthetics, at the point of utilizing the environment for appreciation activities and works of art will be seeking alternatives as well as research on inhibiting factors.

Curriculum Structure at SMA Negeri 2 Indramayu, which is describing as containing 1) Pattern and composition of subjects 2) Student and Satdik needs of 3) Allocation of face-to-face time 4) Utilization of 4 additional hours.

Curriculum Structure of Indramayu 2 Public High School in its development pattern is still has continued. Only in the pattern and arrangement of subjects, intensification of development and discussion will continue. The curriculum structure in SMA Negeri 2 Indramayu also includes KTSP / Curriculum 2018.

The study load in ideal conditions is 42 minutes. The learning burden at Indramayu 2 Public High School is 44 minutes.

The Education Calendar at Indramayu 2 Public High School was made a unique guide based on the Provincial / District Education Office. It intends that teachers in SMA 2 Indramayu can determine the sufficient week and productive day of the year create an annual program and a semester program on the preparation of learning tools.

\section{Discussion}

\section{School Quality}

Cultivation of moral values is part of the quality of schools, as explained by Buhren (2015) that ... The definition of school quality is a process of social negotiation, where all participants (teachers, parents, students, and politicians) should take part. This opinion states that the quality of schools is a process of social negotiation; for this, it requires the role of all participants. Participants in this social 
negotiation are teachers, parents, students, and politicians. Lagrosen (1999) states that the dimensions of quality are pupils, parents, personnel. The pupils (students) with indicators of participation, effectiveness, security, well-being. The parents (parents) with indicators of participation, effectiveness, commitment, attentiveness, security. The personnel with indicators of meaningfulness, security, respect. Overall, these opinions have analyzed that instilling moral values is needed for social negotiations between teachers, parents, students, and politicians.

Parent, business, and local community support is part of school quality, as explained by Lagrosen (1999) that the dimensions of school quality consist of 3 elements, namely pupils, parents, and personnel.

Purposeful and robust leadership, concern for students. A balanced and challenging curriculum. These three factors are part of the quality of schools (Sallis, 2005 in Fadli 2017).

Content standards whose scope is material and level of competence, Process Standards associated with implementing learning to achieve graduate competency standards, Graduates Competency Standards. Infrastructure Standards, Management Standards, Financing Standards, Assessment Standards. These standards are all contained in the National Education Standards. National Education Standards are one of the country's goals in the context of education in Indonesia as explained by Elahi \& llyas (2019) that "As school quality has labeled with the goodness of input, goodness of output, proper methods and practices, fulfillment of the desires of community and objectives of state or country. This opinion can be analyzed that the quality of schools has characterized by the presence of inputs, the right methods, and the right teaching practices, besides fulfilling the desires of consumers and the fulfillment of state objectives.

\section{Principal's Leadership}

The school principal, as part of his contribution to the health and success of the school, to carry out several administrative functions, including regular teaching supervision. Following Rachmawati's explanation (2013) that the principal has the ability as a supervisor, emotional stability, decisiveness in making decisions, teaching skills, social skills, knowledge of human relations.

The principal is to assist and guide teachers to translate national policy provisions on education and curriculum or syllabus contents into lessons that can be applying to learn activity. That is in line with the opinion presented by Ervay (2006) that school administrators are tasking with guiding teachers to be competent and professional.

The principal supports the teaching methods of teachers and the modification of their approaches and teaching materials. That is in line with the opinion presented by Thornton (2014) that as an education leader is continually opening new learning. This learning includes having an understanding of the learning process.

The principal allocates resources and materials. The principal tasks and provides feedback about teaching methods and techniques. Thornton (2014) that as an education leader, regularly opens new learning. This learning includes having an understanding of the learning process. 


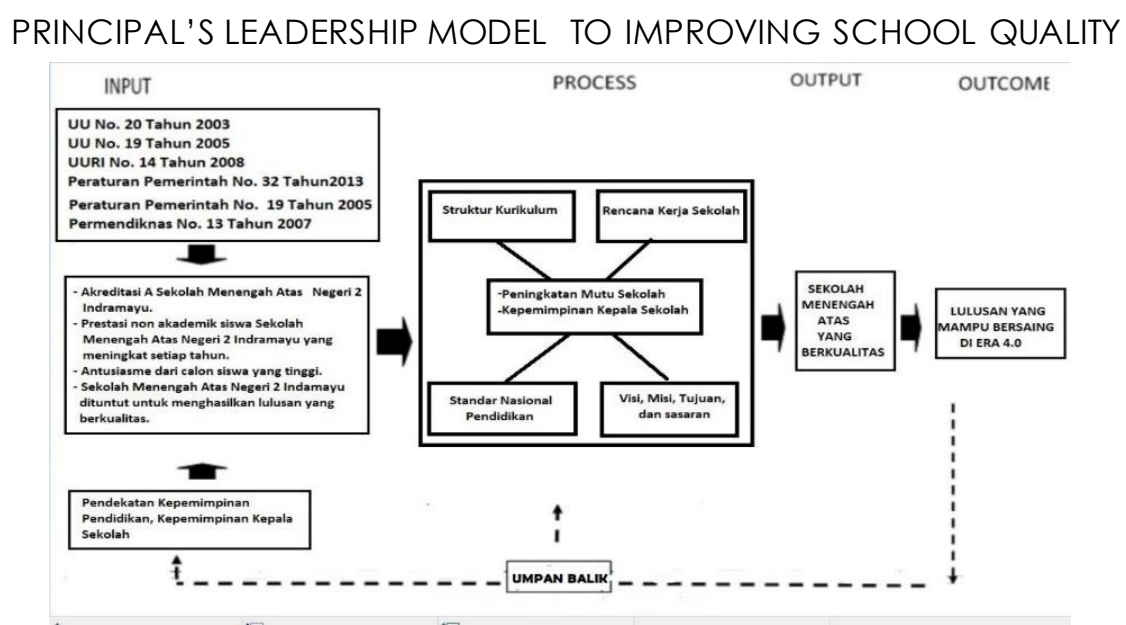

Figure 1

Explanation of figure 1 is as follows:

The elements in the principal's leadership model in improving the quality of the school are as follows

\section{Input}

Inputs from this model are State High Schools which need have upgraded concerning;

UU no. 20 of 2003 concerning the National Education System

UU no. 19 of 2005 concerning National Education standards

UU RI No. 14 of 2008 concerning Teachers and Lecturers

Government Regulation No. 19 of 2005 concerning the National Education System

Minister of Education Regulation No. 13 of 2007 concerning School Principal Competencies

From the input it can be concluded that to improve the quality of schools it is necessary to refer to Law No. 20 of 2003 concerning the National Education System, Law No. 19 of 2005 concerning National Education Standards, Law of the Republic of Indonesia No. 14 of 2008 concerning Teachers and Lecturers, Government Regulation No. 19 of 2005 concerning the National Education
System, and Permendiknas No. 13 of 2007 concerning School Principal Competencies.

\section{Process}

This model is a principal's leadership model in improving school quality with the following elements:

Vision, Mission, Objectives, and Targets; School Work Plans; Curriculum Structure; National Education Standards.

\section{Output}

If the principal's leadership model in improving the quality of the school is implementing correctly, a quality public high school will be realizing.

\section{Outcome}

The expected outcome of quality public high schools is the realization of graduates who can compete in the 4.0 era

\section{CONCLUSION}

Strengthening school quality is part of the principal's leadership strategy. Quality schools are closely related to the principal's leadership. Improving the quality of schools is a process towards the realization of quality schools. This process is inseparable from the organization's vision, mission, goals, and objectives. Besides, this process is related to school 
work programs and national education standards. This research has shown that the principal's leadership has a role in strengthening school quality.

Strategies undertaken by school principals in improving school quality which include regular teaching supervision, helping and guiding teachers to translate national policy provisions on education and curriculum or syllabus contents into lessons that have applied to learning, supporting teacher teaching methods and modifying approaches and their teaching materials, allocating resources and materials, often visiting classrooms for teaching purposes, asking for and giving feedback about teaching methods and techniques, using data to focus on improving curriculum or teaching approaches to maximize student achievement, using data and input faculty to determine staff development activities that strengthen teacher teaching skills.

\section{ACKNOWLEDGMENT}

Thanks to the University of Wiralodra for assisting in funding this research funding through internal grants. Besides, researchers say thanks to those who have helped in this research to completion.

\section{REFERENCES}

Buhren, C.G. (2015). "School Evaluation in Germany: A means to improve school quality" In School-Based Evaluation: An International Perspective. 261 279. DOl.org/10.1016/S14747863(02)80016-3

Chen, C \& Silverthorne, C (2005). Leadership effectiveness, leadership style, and employee

readiness.Leadership \& Organizational Development Journal vol 26 (2) 280-288,

Edwards, G., Schedlitzki, D., Ward, J., Wood, M. (2015). Exploring Critical Perspectives of Toxic and Bad Leadership Through Film. advances in Developing Human Resources 17 (3) 363375

Elahi, F \& Ilyas, M. (2019). Quality Management Principles and School Quality: Testing moderation of professional certification of a school principal in private schools of Pakistan. The TQM Journal, https://doi.org/10.1108/TQM11-2018-0173

Engel, L.C. \& Rutkowski, D. (2014). Global Influences on National Definitions of Quality Education: examples fro Spain and Italy. Policy Futures in Education (12) 6

Ervay, S. (2006). Academic Leadership in America's Public Schools. NASSP Bulletin Vol 90, No. 2, 7786

Fadhli, M. (2017). Manajemen Peningkatan Mutu Pendidikan. TADBIR Jurnal Studi Manajemen Pendidikan (1) 2

Hayati, A.A. (t.t) Pendidikan Nilai Moral melalui Program Living Values Activities Dalam Pengembangan Karakter Siswa di SMA Plus Muthahhari Bandung. Internet, 25 Maret 2019 
Hofmeyer, A., Sheingold, B.H., Klopper, H.C., Warland, J. (2015). Leadership in Learning and Teaching in Higher Education: Perspectives of Academics in Non-Formal Leadership Roles. Contemporary Issues in Education Research- Third Quarter Vol 8 (3) 181-190

Hoy, C., Jardine_Bayne, C., \& Wood, M. (2000). Improving Quality in Education. London: Palmer Press

Imhangbe, OS., Okecha, RE., Obozuwa, J. (2018). Principals' leadership styles and teachers' job performance: Evidence from Edo State, Nigeria. Educational Management Administration \& Leadership Journal $1-16$

Lagrosen, S. (1999). TQM Goes to School: an effective way of improving school quality. The TQM Magazine, Vol 11 No 5, pp 328-332

Laurie, R., Nonoyama-Tarumi, $Y_{\text {., }}$ McKeown, R., Hopkins, C. (2016). Contributions of Education for Sustainable Development (ESD) to Quality Education: A synthesis of research. Research 10 (2) 226242

Okinyi, N.P., Kwaba, J.G., Nyabuto, N.N. (2015). The Role of Leader in Transforming Learners and Learning in the Higher Learning Institutions in Kenya. Journal of Education and Practice Vol 6 (25) $105-116$
Oktriany, W.H. \& Triastuti, R. (t.t). Peningkatan Mutu Sekolah Melalui Pengembangan Manajemen Laboratorium Komputer. Universitas Kristen Satya Wacana

Pandit, A \& Jhamtani, A. (2011). Growing Leaders Grows Profits - A Case Study in Leadership Development. Management Case: 15(2) 193-200

Pidarta, M. (2011). Manajemen Pendidikan Indonesia. Jakarta: Rineka Cipta

Rachmawati, Y. (2013). Pengaruh Kepemimpinan Kepala Sekolah Terhadap Kinerja Guru. Jurnal Pendidikan Ekonomi IKIP Veteran Semarang, Vol 1 (1) 19 $-28$

Rosdina, Murniati, Yusrizal. (2015). Perilaku Kepemimpinan Kepala Sekolah Dalam Peningkatan Kinerja Guru pada SD Negeri 2 Lambheu Kabupaten Aceh Besar. Jurnal Administrasi Pendidikan Pascasarjana Universitas Syiah Kuala pp 69-78

Sallis, E. (2002). Total Quality Management in Education. Third edition. London: Kogan Page

Sammons, P., Hillman, J., and Mortimore, P. (2007). Key Characteristics of Effective Schools: A review of school effectiveness research A report by the Institute of Education for the Office for Standards in Education. 
Snaebjornsson, I.M., Edvardsson, I.R., Zydziunaite, V, Vaiman, V. (2015). Cross-Cultural Leadership: Expectations of Gendered Leaders' Behavior. Article Sage Open April June $20151-8$
Thornton, K. (2014). Mentors as educational leaders and change agents. International Journal of Mentoring and Coaching in Education, Vol 3 (1) $18-31$ 